\title{
Pengelolaan kualitas air anak Sungai Kampar sekitar penambangan galian C (sirtu) di Desa Palung Raya Kecamatan Tambang Kabupaten Kampar
}

\author{
Monalisa Hasibuan ${ }^{1}$, Rifardi ${ }^{2}$, Zulkifli ${ }^{3}$ \\ ${ }^{1}$ Pascasarjana Ilmu Lingkungan Program Pascasarjana Universitas Riau \\ ${ }^{2,3}$ Fakultas Perikanan Dan Kelauatan Universitas Riau
}

\begin{abstract}
There are many mining sites found around Kampar watershed, specifically in Tambang subdistrict. These mining site are scattered in villages, such as Palung Raya village. This research is conducted to analyze the influence of mining to water quality, rate of land erosion, pollutant load, assimilation capacity, social condition and community economy and mining area management. Survey method and quantitative descriptive approach are chosen to collect data from represented population, which are water, soil and the community around mining site. Insitu parameters are temperature, $p H$, $D H L, D O$, and exsitu parameters are TDS, TTS, Fe, texture, soil permeability and plankton. Mining activities have yet to influence water quality, but there's a fluctuation in physical and chemical parameters, and the average of measurement is under the quality standard of PP Number 82 Year 2001, analog with plankton biology parameter, moderate diversity, no show of dominant type and balanced uniformity. The rate of erosion on slope of 0-8 \% is 16,1 ton/ha/year with TBES, and on slope of 8-15\% is 72,7 ton/ha/year with TBESB. The value of TDS and TSS for assimilation capacity is over the pollutant load from pollutant source. Mining activity has yet to influence the social economy condition of the community around mining sites. It's because of the owner and employees are from the outside of the community. Water quality management of Kampar tributary is conducted based on the analysis of influence from mining to water quality, rate of erosion, pollutant load, assimilation capacity and social and economy condition around the mining sites.
\end{abstract}

Keywords: Type C materials (sirtu); water quality; rate of erosion; pollutant load and assimilation capacity

Galian C (sirtu) merupakan sumber daya alam yang tidak dapat diperbaharui dan berguna sebagai bahan bangunan dan pengerasan jalan. Kegiatan penamban gan galian $C$ (sirtu) seringkali menyebabkan kerusakan lingkungan, dan manusia merupakan penyebab utama karena canggihnya teknologi untuk memodifikasi alam. Keberadaan tambang galian C (sirtu) ditengah-tengah masyarakat merupakan wujud usaha masyarakat dalam mempertahankan hidupnya melalui usaha meningkatkan pendapatan.

Kebutuhan bahan bangunan yang semakin meningkat bagi masyarakat sekitar Kabupaten Kampar dan kabupaten/kota tetangga akan menambah PAD Pemerintah Kabupaten Kampar. Kegiatan yang menjanjikan ini turut pula membawa dampak yang merugikan bagi manusia dan lingkungan hidup, berubahnya morfologi dan topografi lahan, dan penurunan produktivitas tanah, manakala kegiatan tersebut tidak dikelolaberdasarkan Peraturan yang berlaku. Merujuk kepada Hamid (2017), dampak negatif kegiatan penambangan galian $C$ terhadap lingkungan adalah terjadinya perubahan air yang keruh sehingga tidak bisa dimanfaatkanolehmasyarakat, dan terjadinya erosi karena terkikis dan terdorong oleh aliran air hujan.

Aktivitas penambangan sangat terasa dampaknya bagi ekosistem sekitar lokasi penambangan, salah satunya adalah ekosistem perairan. Perubahan kualitas air sudah pasti akan terjadi akibat perubahan bentang alam, yang berarti akan berpengaruh terhadap kehidupan makhluk hidup didalamnya. Parameter kualitas air yang cukup penting seperti $\mathrm{pH}$, suhu dan $\mathrm{DO}$ akan mengalami fluktuasi yang berdampak pada perkembangan biota air. Penurunan kualitas air sungai dikarenakan adanya sisa pasir (bahan galian C) yang terbuang ke sungai. Tingginya nilai TSS setelah lokasi penambangan dikarenakan adanya penambahan partikulat yaitu lumpur dan pasir halus yang terbawa oleh air ke sungaiyang berada di sekitar lokasi penambangan (Sofarini, 2011).

Pemantauan kualitas air Sungai Kampar pada segmen Hilir Kabupaten Kampar dengan metode Storet dan Indeks Pencemaran (IP). Telah dilakukan oleh DLHK Prop. Riau tahun 2017 dan 2018, data metode Storet menunjukkan bahwa mutu air yang dipantau berada dalam kondisi buruk (cemar berat) dan metode IP memenuhi baku mutu dan cemar sedang pada titik pantau Desa Danau Bingkuang Kecamatan Tambang.

Daerah Aliran Sungai (DAS) Kampar banyak ditemukan penambangan Galian C (sirtu), khususnya di Kecataman Tambang. Penambangan galian $C$ (sirtu) tersebar di beberapa desa dan dusun di Kecamatan Tambang, sering kali menimbulkan dampak negatif terhadap lingkungan, akan tetapi indikasi kuantitatif dari pengaruh penambangan tersebut terhadap lingkungan terutama bagaimana pengaruh penambangan 


\section{ZONA}

Jurnal Lingkungan

Volume 4, No 2, Oktober 2019, p. 71-82

ISSN : 2502-6496 (Print)

http://zona.pelantarpress.co.id

galian C (sirtu) terhadap kualitas air, seberapa besar laju erosi lahan terbuka dengan adanya penambangan galian C (sirtu), besarnya beban pencemaran pada sumber pencemar dan nilai kapasitasi asimilasi air yang berada di anak Sungai Kampar setelah penambangan galian C (sirtu), belum teridentifikasikan dalam penelitian yang telah dilakukan sebelumnya.

Berdasarkan permasalahan tersebut di atas untuk mendapatkan jawaban tersebut, perlu dilakukan penelitian Pengelolaan kualitas Air Anak Sungai Kampar sekitar Penambangan Galian C (sirtu) di Desa Palung Raya Kecamatan Tambang Kabupaten Kampar, sehingga kegiatan penambangan galian C (sirtu) tidak menurunkan kualitas air Sungai Kampar dan tidak mengganggu kehidupan masyarakat di sekitar penambangan galian C (sirtu) di Desa Palung Raya Kecamatan Tambang Kabupaten Kampar. Penelitian ini bertujuan untuk menganalisis pengaruh penambangan galian $C$ (sirtu) terhadap kualitas airr, laju erosi lahan, beban pencemar dan kapasitas asimilasi, kondisi sosial dan ekonomi masyarakat, dan pengelolaan kualitas air anak Sungai Kampar sekitar penambangan galian C (sirtu) di Desa Palung Raya Kecamatan Tambang Kabupaten Kampar.

\section{METODA PENELITIAN}

Penelitian ini menggunakan metode surveidan pendekatan deskriptif kuantitatif, pada lima stasiun penelitian di sekitar lokasi tambang dan pemukiman penduduk bulan Juli sampai dengan bulan Agustus (delapan minggu) Tahun 2019. Metode survei dilakukan dengan mengumpulkan data dari populasi yang terwakilkan (sampel). Pendekatan deskriptif kuantitatif digunakan untuk menggambarkan kondisi lapangan dalam bentuk perhitungan, dimana hasil penelitian yang diperoleh adalah gambaran kualitas air anak Sungai Kampar sekitar penambangan galian C (sirtu) di Desa Palung Raya pada waktu penelitian. Analisa data penelitian insitu dan exsitu parameter kualitas air berdasarkan Peraturan Baku Mutu Peraturan Pemerintah Nomor 82 Tahun 2001 tentang Pengelolaan Kualitas Air dan Pengendalian Pencemaran Air kelas II, Keputusan Menteri Lingkungan Hidup No. 115 Tahun 2003 tentang Pedoman Penentuan Status Mutu AirKeputusan Menteri Lingkungan Hidup No. 115 Tahun 2003 tentang Pedoman Penentuan Status Mutu Air dan ) mengacu pada Sembel (2012), Sudinno (2012), Baherem et al. (2014) dan Yanti, et al. (2014)) serta Odum (1996). Laju erosi lahan terbuka disekitar penambangan galian C (sirtu) mengacu pada Asdak (2007) Peraturan Menteri Kehutanan Nomor : P. 32/MENHUT-II/2009 tentang Tata Cara Penyusunan Rencana Teknik Rehabilitasi Hutan dan Lahan Daerah Aliran Sungai. Uji validitas kuesioner sosial dan ekonomi mengacu pada Pearson Product Moment dan Slovin Michael. Data yang diperoleh dari insitu dan exsitudigambarkan secara statistik SPSS dan grafik untuk mengetahui sebaran data mengikuti distribusi normal.

\section{HASIL DAN PEMBAHASAN}

\section{Pengaruh Penambangan Galian C (sirtu) terhadap Kualitas Air Anak Sungai Kampar di Desa Palung Raya}

Kualitas air sekitar penambangan galian C (sirtu) di Desa Palung Raya Kecamatan Tambang berdasarkan parameter fisika, kimia dan biologi. Hasil pemantauan kondisi umum lokasi penelitian selama pengambilan sampel memperlihatkan kondisi cuaca rata-rata cerah dan suhu air rata-rat $28^{0}-29^{\circ} \mathrm{C}$. Data parameter DHL setiap stasiun dan tanggal pengamatan disajikan pada Tabel 1.

Tabel 1. Data Pengukuran DHL Air Setiap Stasiun dan Tanggal Pengamatan

\begin{tabular}{ccccccc}
\hline & \multicolumn{5}{c}{ Ulangan } & \multirow{2}{*}{ Rata-rata } \\
\cline { 2 - 5 } Stasiun & 6 Juli & 13 Juli & 20 Juli & 28 Juli & 3 Agus & 17,85 \\
S1 & 10,84 & 20,60 & 14,15 & 13,55 & 30,1 & 20,11 \\
S2 & 16,49 & 18,4 & 15,63 & 31,90 & 18,14 & 22,97 \\
S3 & 16,08 & 18,96 & 18,20 & 22,20 & 39,40 & 19,74 \\
S4 & 19 & 19,50 & 18,40 & 22,40 & 19,40 & 17,83 \\
S 5 & 17,34 & 19,20 & 17,42 & 17,34 & 17,87 & \\
\hline
\end{tabular}

Keterangan : satuan $\mu \mathrm{mhos} / \mathrm{cm}$

Hasil pengukuran DHL Stasiun S1, S2, S3, S4 dan S5 setiap tanggal ulangan pada Tabel 1, cendrung berfluktuasi rata-rata berkisar $17-23 \mu \mathrm{mhos} / \mathrm{cm}$. Konduktivitas atau DHL adalah kemampuan air untuk meneruskan listrik dari ion-ion logam yang larut. Ion-ion yang berasal dari tanah, padatan 


\section{ZONA}

Jurnal Lingkungan

ISSN : 2502-6496 (Print)

lumpur dan pasir aktivitas penambangan yang masuk ke anak sungai sekitar lokasi penambangan galian $C$ (sirtu). Mineral galian C (sirtu) mengandung unsur Si, Mg, Ca non logam dan besi (Fe) logam. Nilai DHL pada setiap stasiun berfluktuasi kemungkinan berasal dari ion besi yang larut dalam suasana asam ( $\mathrm{pH} 5$ 6 ). Hal ini mengacu kepada hasil penelitian Rizqan et al., (2016), dimana waktu penambangan galian C (sirtu) zat-zat terlarut yang bersifat asam seperti $\mathrm{SiO}_{2}$ meningkat dan terlepasnya mineral-mineral tersebut pada saat penambangan dilakukan. Menurut Effendi (2015), Daya Hantar Listrik (DHL) menggambarkan garam-garam terlarut yang dapat terionisasi dan melalui media air meneruskan arus listrik.Perairan alami DHL sekitar 20 - $1500 \mu \mathrm{mhos} / \mathrm{cm}$, dan Situmorang (2017) juga menyatakan bahwa konduktivitas atau daya hantar listrik diukur untuk mengetahui gambaran kualitas air dari total zat padat terlarut yang mengandung ion menghantar arus listrik.

Tabel 2. Data Pengujian Konsentrasi TDS air Setiap Stasiun dan Tanggal Pengamatan

\begin{tabular}{ccccccc}
\hline & \multicolumn{5}{c}{ Ulangan } & Rata-rata \\
\cline { 2 - 6 } Stasiun & 6 Juli & 13 Juli & 20 Juli & 28 Juli & 3 Agus & 9,94 \\
S1 & 16 & 9 & 9 & 7,89 & 7,8 & 8,07 \\
S2 & 10 & 7 & 9 & 7,16 & 7,2 & 8,74 \\
S3 & 8 & 8 & 11 & 8,08 & 8,6 & 10,46 \\
S4 & 8 & 10 & 8 & 14,8 & 11,5 & 9,6 \\
S 5 & 7 & 9 & 11 & 10,9 & 10,1 & \\
\hline
\end{tabular}

Keterangan : PP No. 82 Tahun 2001, Baku Mutu konsentrasi TDS $=1.000$ mg/L

Hasil pengujian konsentrasi TDS pada Tabel 2, rata-rata berkisar 8-10 mg/L. Pada stasiun S1, S2, S3, S4 dan S5 konsentrasi TDS pada setiap perulangan menunjukan angka yang masih di bawah baku mutu (1.000 mg/L).Mengacu kepada Asdak (2007), menyatakan bahwa sedimen yang dijumpai di dalam sungai baik terlarut atau tidak terlarut berupa pasir, liat dan lainnya tergantung dari ukuran partikel. Partikel sedimen yang ukurannya kecil dapat terlarut dalam aliran air atau anak sungai, dan partikel ukuran lebih besar tidak dapat larut dalam aliran air atau anak sungai, tetapi terdorong oleh air hujan dan masuk ke dalam sungai.Padatan terlarut (TDS) pada setiap stasiun penelitian diasumsikan berukuran besar cendrung terdorong oleh air hujan pada anak sungai dan masuk ke dalam Sungai Kampar, dan padatan atau partikel yang berukuran kecil sirtu (pasir dan krikil) akan mengendap ke dasar anak sungai membentuk sedimen.

Selanjutnya Rizqan et al., (2016) menyatakan bahwa kekeruhan perairan dapat dipengaruhi oleh bahan-bahan yang melayang di dalam air. Kekeruhan perairan umumnya disebabkan oleh adanya partikelpartikel suspensi seperti tanah liat, lumpur, pasir dan bahan-bahan organik terlarut. Penentuan padatan atau kekeruhan air atau banyaknya intensitas cahaya sangat berguna dalam penentuan kualitas perairan. Banyaknya pembusukan bahan-bahan organik dan tingginya tingkat kekeruhan perairan dapat menyebabkan menurunnya kualitas perairan.Air terlihat keruh pada anak sungai sekitar lokasi penambangan galian $C$ (sirtu) terlihat pada saat hujan, dimana air hujan yang jatuh menyembabkan sedimen atau dasar anak sungai teraduk dan terberbentuk suspensi. Kekeruhan juga terlihat pada saat aktivitas penambangan, dimana air keruh pada anak sungai yang menerima tumpahan tanah, sirtu dan tanah liat. Data parameter konsentrasi TSS setiap stasiun dan tanggal pengamatan disajikan pada Tabel 3.

Tabel 3. Data Pengujian Konsentrasi TSS Air Setiap Stasiun dan Tanggal Pengamatan

\begin{tabular}{lcccccc}
\hline & \multicolumn{5}{c}{ Ulangan } & Rata-rata \\
\cline { 2 - 6 } \multicolumn{1}{c}{ Stasiun } & 6 Juli & 13 Juli & 20 Juli & 28 Juli & 3 Agus & 15,6 \\
S1 & 20 & 52 & 2 & 2 & 2 & 48,8 \\
S2 & 96 & 20 & 50 & 38 & 40 & 38,6 \\
S3 & 16 & 20 & 56 & 47 & 54 & 37,2 \\
S4 & 8 & 64 & 6 & 51 & 57 & 40,2 \\
S 5 & 16 & 140 & 12 & 19 & 14 &
\end{tabular}

Keterangan : PP No. 82 Tahun 200, Baku Mutu konsentrasi TSS = 50 mg/L

Hasil pengujian konsentrasi TSS pada Tabel 3, stasiun S1 sebelum lokasi penambangan galian C (sirtu) pada perulangan tanggal 20 Juli, 28 Juli dan 3 Agustus menunjukkan konsentrasi TSS tetap yaitu 2 $\mathrm{mg} / \mathrm{L}$. Pada tanggal 6 dan 13 Juli terjadi peningkatan konsentrasi TSS, karena 2 (dua) hari sebelum pengambilan sampel, turun hujan. Air hujan menyebabkan sedimen di dasar anak air naik ke permukaan. Pada stasiun S2 dan S3 yang berada di lokasi penambangan galian C (sirtu) konsentrasi TSS berfluktuasi, kondisi ini disebabkan aktivitas penambangan dan pembukaan lahan untuk ditambang.Lumpur, pasir 


\section{ZONA}

Jurnal Lingkungan

ISSN : 2502-6496 (Print)

Volume 4, No 2, Oktober 2019, p. 71-82 http://zona.pelantarpress.co.id

halus dan longsoran tanah (top soil) yang ditumpuk di sekitar lokasi penambangan masuk ke anak sungai dan terbawa hingga ke stasiun S4 dan S5. Pada stasiun S5 perulangan tanggal 13 Juli menunjukkan konsetrasi TSS yang sangat tinggi yaitu $140 \mathrm{mg} / \mathrm{L}$, karena hujan turun 2 (dua) hari sebelum pengambilan sampel. Stasiun S5 berada di pemukiman penduduk dan air larian dari lahan kebun sawit dan tanaman pisang di kiri kanan serta badan jalan masuk ke anak sungai, air terlihat keruh dan berpartikel.

Mengacu pada Sofarini (2011) bahwa kekeruhan menunjukkan tingkat kejernihan aliran air atau kekeruhan aliran air yang diakibatkan oleh unsur-unsur muatan sedimen, baik yang bersifat mineralatau organik. Kekeruhan dapat dianggap sebagai indikator kemampuan air dalam meloloskan cahaya matahari, kemudian disebarkan atau diserap oleh air tersebut. Semakin kecil atau rendah tingkat kekeruhan suatu perairan, semakin dalam cahaya dapat masuk ke dalam badan air dan semakin besar kesempatan bagi vegetasi aquatis untuk melakukan proses fotosintesis maka semakin besar persediaan oksigen yang ada di dalam air.

Pada saat- saat tertentu akan terjadi penurunan kualitas air. Hal ini terjadi karena intrusi air pada proses pembusukan tanaman air yang mati pada saat musim kemarau dan tiba-tiba terendam oleh air, akibatnya proses dekomposisi tidak dapat berlangsung dengan baik. Sebagai dampak dari proses alam ini adalah terjadinya pembusukan air yang mengakibatkan air menjadi asam ( $\mathrm{pH}$ air turun) dan kadar DO juga menjadi rendahSelanjutnya Suherman et al., (2015), mengemukakan tentang kriteria kesesuaian perairan untuk kepentingan perikanan berdasarkan nilai TSS. Nilai TSS $<25 \mathrm{mg} /$ liter tidak berpengaruh terhadap kepentingan perikanan, antara 25 dan $80 \mathrm{mg} /$ liter memberikan sedikit pengaruh terhadap kepentingan perikanan, antara 81 dan $400 \mathrm{mg} /$ liter kurang baik bagi kepentingan perikanan dan $>400$ $\mathrm{mg} /$ liter tidak baik.

Tabel 4. Data Pengukuran $\mathrm{pH}$ Air Setiap Stasiundan Tanggal Pengamatan

\begin{tabular}{ccccccc}
\hline & \multicolumn{5}{c}{ Ulangan } & \\
\cline { 2 - 5 } Stasiun & 6 Juli & 13 Juli & 20 Juli & 28 Juli & 3 Agus & Rata-rata \\
\hline S1 & 6,79 & 5,07 & 6,49 & 6,06 & 6,09 & 6,1 \\
S2 & 5,62 & 5,05 & 6,39 & 5,76 & 6,04 & 5,77 \\
S3 & 5,28 & 5,19 & 5,72 & 5,59 & 5,96 & 5,55 \\
S4 & 5,48 & 5,08 & 5,63 & 5,87 & 6,02 & 5,62 \\
S 5 & 5,48 & 5,21 & 4,43 & 5,48 & 5,91 & 5,30 \\
\hline
\end{tabular}

Keterangan : PP No. 82 Tahun 200, Baku Mutu pH 6 - 7

Hasil pengukuran $\mathrm{pH}$ pada Tabel 4, cendrung berfluktuasi berkisar 5 - 6. Stasiun S1 yang berada sebelum kegiatan penambangan galian $\mathrm{C}$ (sirtu) pada setiap perulangan memperlihatkan $\mathrm{pH}$ cendrung berada pada kisaran 6. $\mathrm{pH}$ air pada tanggal 13 Juli di semua stasiun menunjukkan angka 5, dimana suhu udara pada saat pengambilan air $29^{\circ} \mathrm{C}$ sampai dengan $31^{\circ} \mathrm{C}$ dan suhu air $28^{\circ} \mathrm{C}$ sampai dengan $29^{\circ} \mathrm{C}$. pH air pada tanggal 20 Juli terjadi penurunan dari stasiun S1 sampai ke stasiun S5, suhu berfluktuasi berkisar $27{ }^{\circ} \mathrm{C}$ sampai dengan $29^{\circ} \mathrm{C}$, dimana pada tanggal tersebut ada dua aktivitas di lokasi penelitian yaitu penambangan dan pembukaan lahan untuk ditambang. Mineral-mineral yang terdapat pada lumpur, pasir halus dan longsoran tanah (top soil) masuk ke dalam anak sungai. Mengacu pada Rizqan et al., (2016), pH yang rendah terjadi pada kondisi suhu meningkat disebabkan karena meningkatnya zat-zat terlarut yang bersifat asam seperti senyawa anorganik silika oksida dan phospat, senyawa organik dari biota dan tanaman air yang mati di dasar air.

Menurut Effendi (2015), nilai $\mathrm{pH}$ suatu perairan dipengaruhi oleh beberapa faktor antara lain adanya aktivitas fotosintesis, suhu, kandungan oksigen dan adanya anion dan kation di dalam air. Selanjutnya Baherem et al., (2014) menyatakan nilai $\mathrm{pH}$ menggambarkan suasana asam dan basa pada air. Suasana air akan mempengaruhi kehidupan biologi di dalam air. Kondisi $\mathrm{pH}$ dapat mempengaruhi tingkat toksisitas suatu senyawa kimia, proses biokimia perairan dan proses metabolisme organisme air. 


\section{ZONA}

Jurnal Lingkungan

ISSN : 2502-6496 (Print)

Volume 4, No 2, Oktober 2019, p. 71-82 http://zona.pelantarpress.co.id

Tabel 5. Data Pengukuran Konsentrasi DO Air Setiap Stasiun dan Tanggal Pengamatan

\begin{tabular}{lrrrrrr}
\hline & \multicolumn{5}{c}{ Ulangan } & \\
\cline { 2 - 6 } Stasiun & \multicolumn{1}{c}{ 6 Juli } & 13 Juli & 20 Juli & 28 Juli & 3 Agus & Rata-rata \\
\hline S1 & 3,79 & 4,8 & 4,46 & 4,82 & 3,95 & 4,36 \\
S2 & 3,85 & 4,96 & 3,82 & 3,24 & 4,79 & 4,13 \\
S3 & 3,1 & 5,53 & 3,79 & 3,43 & 5,05 & 4,18 \\
S4 & 3,45 & 5,21 & 4,46 & 3,84 & 4,03 & 4,2 \\
S5 & 2,9 & 4,28 & 4,8 & 2,9 & 4,96 & 4,0 \\
\hline
\end{tabular}

Keterangan : PP No. 82 Tahun 2001, Baku Mutu parameter DO = 4 mg/L

Hasil pengukurankonsentrasi DO pada Tabel 5, rata-rata $4 \mathrm{mg} / \mathrm{L}$ pada stasiun S1, S2, S3 dan S4, berbeda dengan stasiun S5 dimana aliran air melalui pemukiman penduduk. Konsentrasi DO berfluktuasi pada setiap tanggal pengukuran sampai dengan angka 2. Fluktuasi konsentrasi DO pada stasiun S5 kemungkinan dipengaruhi oleh adanya limbah domestik. Penguraian bahan (limbah) organik oleh organisme (dekomposisi) yang mempengaruhi kadar oksigen terlarut dalam air. Semakin banyak jumlah limbah organik dalam air akan berdampak berkurangnya oksigen terlarut sebagai akibat tingginya konsumsi oksigen untuk proses penguraian.

Mengacu pada Heffendi (2015) yang menyatakan bahwa sumber oksigen terlarut pada perairan tawar dapat berasal dari difusi oksigen yang terdapat di atmosfer dan aktifivitas fotosintesis oleh tumbuhan air dan fitoplanton. Kadar oksigen terlarut juga berfluktuasi secara harian (diurnal) dan musiman, tergantung pada pencampuran (mixing) dan pergerakan (turbulance) massa air, respirasi dan limbah (effluent) yang masuk ke badan air. Data parameter konsentrasi Fe setiap stasiun dan tanggal disajikan pada Tabel. 6 .

Tabel 6. Data Pengujian Konsentrasi Fe Air Setiap Stasiun dan Tanggal Pengamatan

\begin{tabular}{lrrrrrr}
\hline & \multicolumn{5}{c}{ Perulangan } & \\
\cline { 2 - 6 } Stasiun & 6 Juli & 13 Juli & 20 Juli & 28 Juli & 3 Agus & Rata-rata \\
\hline S1 & 0,83 & 0,5 & 0,47 & 1,93 & 1,97 & 1,14 \\
S2 & 1,5 & 0,39 & 0,77 & 1,94 & 2,3 & 1,38 \\
S3 & 1,25 & 1,31 & 0,93 & 1,58 & 2,58 & 1,53 \\
S4 & 1,25 & 1,08 & 0,74 & 1,73 & 2,5 & 1,46 \\
S5 & 1,24 & 1,29 & 0,68 & 1,76 & 2,49 & 1,49 \\
\hline
\end{tabular}

Keterangan : PP No. 82 Tahun 2001, Baku Mutu parameter Fe : - mg/L (kecuali kelas I)

Hasil pengujian konsentrasi Fe pada Tabel 4.6, rata-rata berkisar 1- 1,5 mg/L. Pada stasiun S1, S2, S3, S4 dan S5 konsentrasi Fe pada setiap tanggal pengambilan sampel berfluktuasi. Konsentrasi besi cukup tinggi pada perulangan tanggal 3 Agustus 2019 diasumsikan karena adanya aktivitas pembukaan lahan untuk ditambang dan $\mathrm{pH}$ air di sekitar lokasi tambang cendrung asam. Mengacu kepada Effendi (2015), yang menyatakan fenomena badan sungai yang menerima aliran air asam dengan kandungan besi cukup tinggi, berasal dari daerah pertambangan.

Menurut Rizqan et al., (2016) menyatakan bahwa konsentrasi Fe meningkat karena terlepasnya dari mineral-mineral pembentuk pasir dan batuan pada saat penambangan pasir dilakukan. Sumber besi di alam adalah pyrite $\left(\mathrm{FeS}_{2}\right)$, hematite $\left(\mathrm{Fe}_{2} \mathrm{O}_{3}\right)$, magnetite $\left(\mathrm{Fe}_{3} \mathrm{O}_{4}\right)$, limonite $[\mathrm{FeO}(\mathrm{OH})]$, goethite $\left(\mathrm{HFeO}_{2}\right)$ dan ochre $\left[\mathrm{Fe}(\mathrm{OH})_{3}\right]$. Senyawa besi pada umumnya bersifat sukar larut pada $\mathrm{pH}$ 7,5 - 7,7 dan cukup banyak terdapat di dalam tanah. Mengacu kepada Peraturan Pemerintah Nomor 82 Tahun 2001 tentang Pengelolaan Kualitas Air dan Pengendalian Pencemaran Air, klasifikasi dan kriteria mutu air untuk konsentrasi logam besi $(\mathrm{Fe}$ ) peruntukkan kelas I batas maksimum $0,3 \mathrm{mg} / \mathrm{L}$ dan kelas II sampai dengan IV tidak dipersyaratkan. Parameter biologi yang dilakukan pada penelitian ini adalah plankton (fitoplankton dan zooplankton) disekitar penambangan galian C (sirtu), dapat dilihat dari deskripsi Keanekaragaman (H') Gambar 1, Keseragaman (E) Gambar 2 dan Dominansi (C) Gambar 3 pada setiap stasiun penelitian. 


\section{ZONA}

Jurnal Lingkungan

Volume 4, No 2, Oktober 2019, p. 71-82

ISSN : 2502-6496 (Print)

http://zona.pelantarpress.co.id

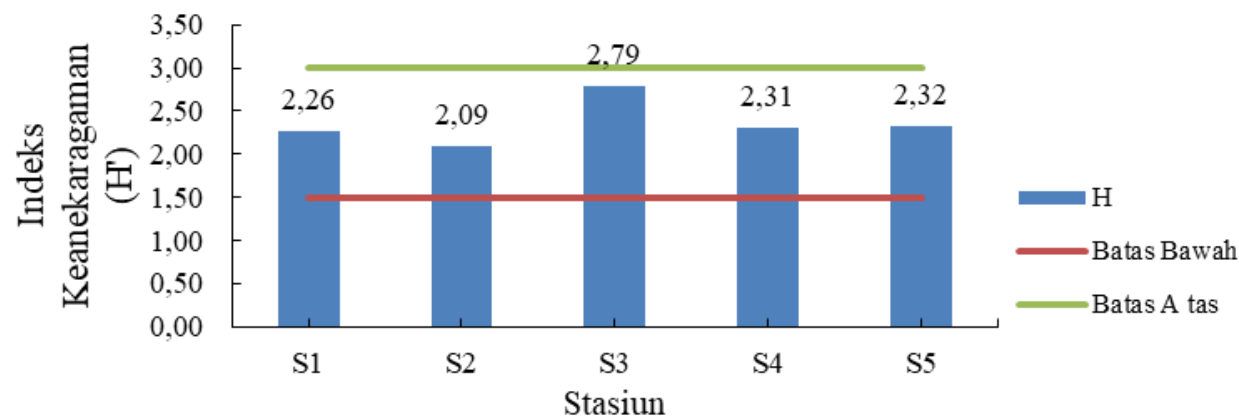

Gambar 1. Indeks Keanekaragaman (H') Plankton

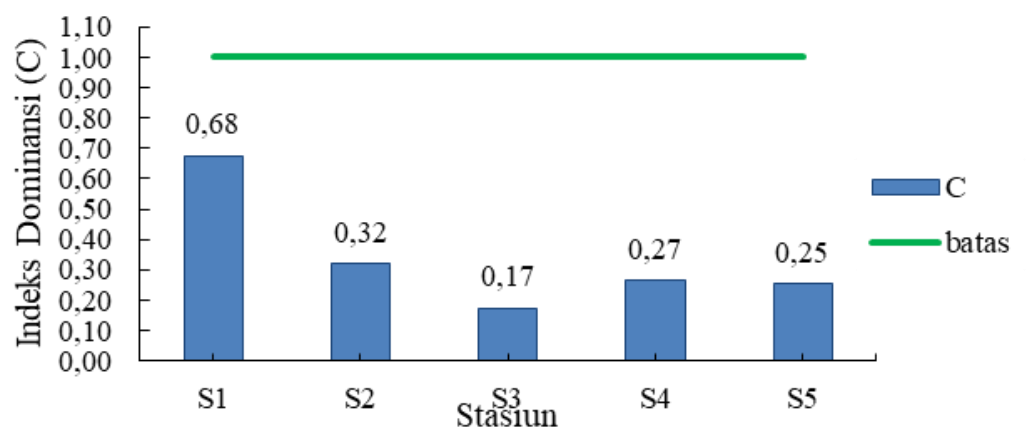

Gambar 2. Indeks Dominansi (C) Plankton

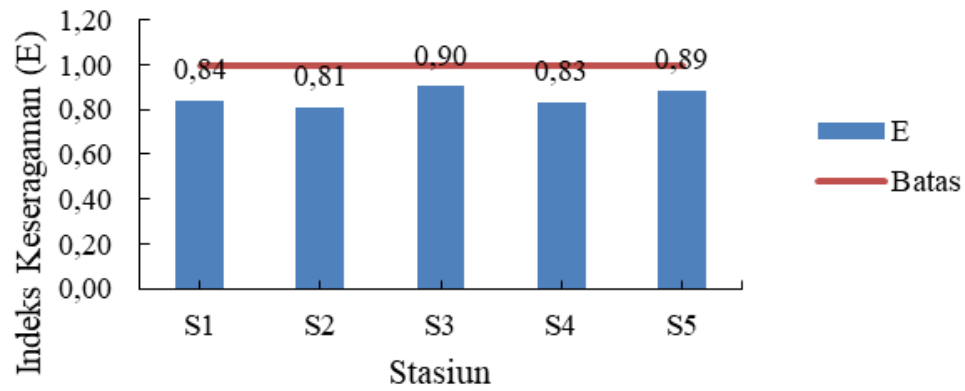

Gambar 3. Indeks Keseragaman (E) Plankton

Pada Gambar 1, Indeks Keanekaragaman ( $\left.\mathrm{H}^{\prime}\right)$ plankton pada setiap stasiun pengamatan menunjukan nilai sedang, berada pada Nilai $\mathrm{H}^{\prime}$ besar dari 1,5 atau kurang dari 3, Gambar 2 Indeks Dominansi (C) plankton pada setiap stasiun pengamatan menunjukan nilai kurang dari 1 atau $<1$, dimana menggambarkan tidak ada jenis plankton yang dominan, dan pada Gambar 3 Indeks Keseragaman (E) plankton pada setiap stasiun pengamatan mendekati 1 atau besar dari 0,5, dimana menggambarkan keseragaman plankton dalam suatu perairan berada dalam keadaan seimbang, tidak terjadi persaingan terhadap tempat maupun sumber nutrisi. Deskripsi H', C dan E tersebut berkaitan dengan kualitas air sekitar penambangan galian $\mathrm{C}$ (sirtu), dimana $\mathrm{pH}$ cendrung asam, air cendrung keruh dan berpartikel (konsentrasi TSS) serta kandungan oksigen yang berada pada batas minimum kebutuhan biota air. Mengacu kepada Sofarini (2011), air tawar alami yang berada pada $\mathrm{pH} 4$ sampai dengan 9, masih dalam batas toleransi untuk penggunaan dalam pertanian dan perikanan. Baherem et al., (2014) menyatakan bahwa ikan dan biota airdapat hidup pada kondisi kadar oksigen terlarut $(\mathrm{DO}=$ oxsygen demand $)$ dalam air berkisar 3 - $4 \mathrm{mg} / \mathrm{L}$.

Menurut Suherman et al., (2015), apabila nilai TSS di lokasi penambangan dan setelah lokasi penambangan tinggi, dikarenakan adanya penambahan partikulat yaitu lumpur dan pasir halus yang terbuang ke sungai membentuk sedimen. Sedimen akan menyebabkan hilangnya tempat memijah yang sesuai bagi ikan karena sedimen dapat menutupi substrat sehingga organisme yang membutuhkan substrat sebagai tempat hidupnya dan tempat berlindung menjadi terganggu. 


\section{ZONA}

Jurnal Lingkungan

ISSN : 2502-6496 (Print)

Volume 4, No 2, Oktober 2019, p. 71-82 http://zona.pelantarpress.co.id

Pengaruh Penambangan Galian C (sirtu) terhadap Laju Erosi dari Lahan Terbuka di Desa Palung Raya Kecamatan Tambang

Lokasi penelitian berada pada kemiringan $0-8 \%$ dan $8-15 \%$. Nilai faktor lereng (LS) pada kemiringan $0-8 \%$ adalah 0.25 dan pada kemiringan $8-15 \%$ adalah 1.20 mengacu pada Nursa'ban (2006 dalamSuherman et al., 2015). Besarnya laju erosi dan tingkat bahaya erosi digambarkan pada Tabel 7 , mengacu pada Peraturan Menteri Kehutanan Republik Indonesia Nomor : P. 32/MENHUT-II/2009.

Tabel 7. Laju Erosi (A) dan Tingkat Bahaya Erosi (TBE)

\begin{tabular}{|c|c|c|c|c|c|c|}
\hline Stasiun & $\begin{array}{c}\mathrm{R} \\
\begin{array}{c}\mathrm{MJ} \mathrm{cm} / \mathrm{ha} / \mathrm{jam} \\
/ \text { tahun })\end{array} \\
\end{array}$ & $\begin{array}{c}\mathrm{K} \\
\text { (Ton ha } \\
\text { jam/haMJ/cm) }\end{array}$ & LS & $\mathrm{CP}$ & $\begin{array}{c}\text { A } \\
\text { (ton/ha } \\
\text { /tahun) }\end{array}$ & TBE \\
\hline \multicolumn{7}{|c|}{ Kemiringan $0-8 \%$} \\
\hline I & $1.987,98$ & 0,31 & 0,25 & 0,10 & 15,41 & B \\
\hline II & $1.987,98$ & 0,37 & 0,25 & 0,10 & 18,39 & B \\
\hline III & $1.987,98$ & 0,29 & 0,25 & 0,10 & 14,41 & $\mathrm{~S}$ \\
\hline \multicolumn{7}{|c|}{ Kemiringan $8-15 \%$} \\
\hline IV & $1.987,98$ & 0,27 & 1,20 & 0,10 & 64,41 & SB \\
\hline V & $1.987,98$ & 0,41 & 1,20 & 0,10 & 98,71 & SB \\
\hline VI & $1.987,98$ & 0,23 & 1,20 & 0,10 & 54,87 & SB \\
\hline
\end{tabular}

Keterangan :

Solum tanah dangkal : $30-60 \mathrm{~cm}$

Lahan semak sebagian berumput, $C P=0,10$ (Asdak, 2007)

$\mathrm{B}=$ Berat, $\mathrm{S}=$ Sedang dan $\mathrm{SB}=$ Sangat Berat

Laju erosi rata-rata pada kemiringan $0-8 \%$ adalah 16,1 ton/ha/tahun dan pada kemiringan 8 $15 \%$ adalah 72,7 ton/ha/tahun. TBE pada kemiringan $0-8 \%$ berat dan sedang dan pada kemiringan $8-$ $15 \%$ sangat berat. Berdasarkan hasil tersebut, maka diperlukan upaya-upaya pengelolaan atau konsevasi lahan untuk mengurangi laju erosi sampai pada tingkat yang aman. Upaya-upaya pengelolaan atau konservasi lahan terbuka di sekitar lokasi tambang galian C (sirtu) di Desa Palung Raya, akan dapat mengurangi kekeruhan air dan penurunan kualitas air pada anak Sungai Kampar yang berada di sekitar lokasi penambangan. Hal ini digambarkan oleh plankton dan biota air lainnya yang hidup di anak sungai, meskipun jenis dan jumlahnya berbeda dengan perairan alami. Menurut Fajri dan Garsetiasih (2019), upaya konservasi lahan yang dapat dilakukan adalah dengan segera melakukan penanaman tanaman penutup tanah pada lahan yang telah selesai diekploitasi dengan teknik konservasi yang disesuaikan dengan jenis tanaman yang ditanam dan kondisi lahan.

\section{Pengaruh Penambangan Galian C (sirtu) terhadap Indeks Pencemaran, Beban Pencemaran dan Kapasitas Asimilasi}

Kondisi mutu (status mutu) air yang menunjukkan kondisi cemar atau kondisi baik sumber air dalam waktu tertentu dengan membandingkan terhadap baku mutu air yang telah ditetapkan. Salah satu cara penilaian status mutu air mengacu pada Keputusan Mentri Lingkungan Hidup nomor 115 Tahun 2013 tentang Pedoman Penentuan Status Mutu Air. Peneliti menggunakan metode Indeks Pencemaran (IP). Indeks Pencemaran digunakan untuk menentukan tingkat pencemaran relatif terhadap parameter kualitas air yang diizinkan Gambar 4.

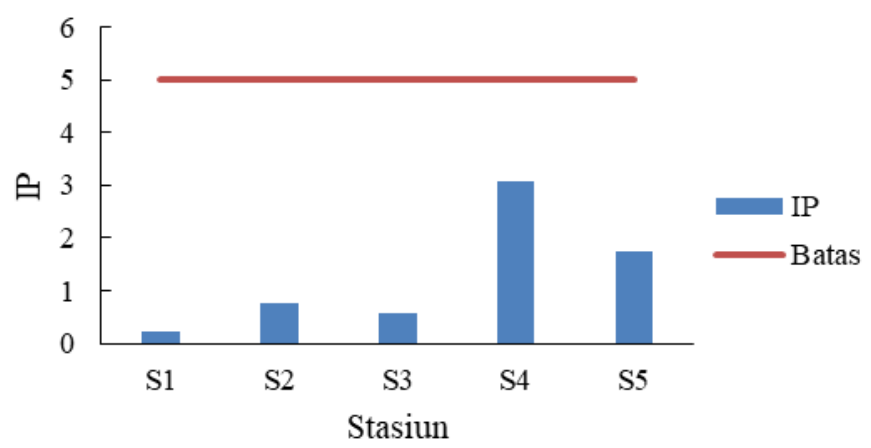

Gambar 4. Grafik Batang IP Setia Stasiun

Pada Gambar 4 grafik batang IP lokasi pengamatan Stasiun S1, S2, S3, S4 dan S5, menunjukkan hasil perhitungan mutu air berdasarkan metode Indeks Pencemaran (IP). Kondisi air di lokasi Stasiun S1, 


\section{ZONA}

Jurnal Lingkungan

Volume 4, No 2, Oktober 2019, p. 71-82

ISSN : 2502-6496 (Print)

http://zona.pelantarpress.co.id

S2 dan S3 berada pada status memenuhi baku mutu $(0 \leq \mathrm{PIj} \leq 1,0)$. Pada Stasiun $\mathrm{S} 1$ yang berada sebelum penambangan galian $C$ (sirtu) nilai IP 0,23 menggambarkan status mutu air tidak tercemar. Stasiun S2 yang berada di sumber pencemaran dari aktivitas penambangan galian $C$ (sirtu ), nilai IP 0,75 juga menggambarkan status mutu air tidak tercemar meskipun menunjukan adanya peningkatan. Penurunan nilai IP pada Stasiun S3 yang berada \pm 50 meter dari Stasiun S2 menjadi 0,56 (status mutu tidak tercemar). Penurunan nilai IP terjadi karena pergerakan (arus) aliran air anak sungai, proses pengenceran dan air mempunyai kemampuan memulihkan dirinya sendiri (self purification) dari bahan pencemar.

Pada Stasiun S4 dan S5 status cemar ringan $(1,0 \leq \mathrm{PIj} \leq 5,0)$. Stasiun S4 berada \pm 100 meter dari Stasiun S3 di pemukiman penduduk, nilai IP 3,08 status mutu air cemar ringan. Menggambarkan sumber pencemar tidak hanya berasal dari aktivitas penambangan galian $C$ (sirtu) akan tetapi juga dari limbah domestik yang dibuang atau terbawa aliran air. Pada Stasiun S5 yang berada \pm 50 meter dari Stasiun S4 menunjukkan penuran nilai IP menjadi 1,76 status mutu air cemar ringan. Stasiun S5 berada di kebun sawit masyarakat dan tidak jauh dari muara aliran air menuju Sungai Kampar. Nilai IP pada setiap stasiun penelitian menggambarkan sumber pencemar dan kondisi lingkungan dimana aliran air sebagai media proses pengenceran, yang dapat memperbaiki status mutu air atau menaikkan nilai IP.

Nilai indeks pencemaran dari lokasi penambangan galian C (sirtu) menuju ke Sungai Kampar cenderung mengalami fluktuasi. Hal ini menunjukkan bahwa kondisi kualitas air berkaitan dengan penggunaan lahan dan aktivitas masyarakat di sekitarnya. Hasil pemantauan Sungai Kampar titik pantau Danau Bingkuang, satus mutu air Sungai Kampar tahun 2017, baik sampai dengan cemar sedang dan Tahun 2018 cemar ringan (Dinas LHK, 2018).

Menurut Agustiningsih et al., (2012), indeks pencemaran merupakan salah satu metode yang digunakan untuk menentukan status mutu air suatu sumber air. Status mutu air menunjukkan tingkat kondisi mutu air sumber air dalam kondisi cemar atau kondisi baik, membandingkan dengan baku mutu yang telah ditetapkan. Kemampuan self purification air sungai terjadi karena penambahan konsentrasi oksigen terlarut dalam air yang berasal dari udara. Mengacu pada Effendi (2015) yang menyatakan bahwa polutan dalam badan air mengalami difusi, penguraian secara kimia (Oksidasi reduksi), biologis (biodegradasi) maupun secara fisika (adsorbsi) yang berproses secara alami.

Nilai Beban Pencemaran aliran air Stasiun S2 yang berada di sumber pencemar dari aktivitas penambangan galian $C$ (sirtu), dihitung berdasarkan pengukuran langsung debit air anak sungai dan konsentrasi parameter TDS dan TSS pada Stasiun S2 sumber pencemar. Debit air anak sungai diperoleh dengan mengalikan lebar, dalam dan kecepatan arus anak sungai di Stasiun S2. Nilai Beban Pencemaran parameter TDS dan disajikan pada Tabel 8 dan 9 .

Tabel 8. Nilai Beban Pencemaran Parameter TDS (mg/L)

\begin{tabular}{lccccc}
\hline \multicolumn{1}{c}{$\begin{array}{c}\text { Stasiun/ } \\
\text { Ulangan/Tg1 }\end{array}$} & $\begin{array}{c}\text { Kec arus } \\
(\mathbf{m} / \mathbf{d t})\end{array}$ & $\begin{array}{c}\text { Lebar } \\
(\mathbf{m})\end{array}$ & $\begin{array}{c}\text { Dalam } \\
(\mathbf{m})\end{array}$ & $\begin{array}{c}\text { Konsentsi } \\
(\mathbf{m g} / \mathbf{L})\end{array}$ & $\begin{array}{c}\text { BP } \\
\text { (Ton/bln) }\end{array}$ \\
\hline S2 & & & & & \\
1 / 6 Juli 2019 & 0,3 & 2,7 & 0,8 & 10 & 16,80 \\
2 / 13 Juli 2019 & 0,2 & 2,7 & 0,8 & 7,0 & 7,84 \\
3 / 20 juli 2019 & 0,6 & 2,7 & 0,8 & 9 & 30,23 \\
4 / 28 Juli 2019 & 0,6 & 2,7 & 0,8 & 7,16 & 24,05 \\
5 / 3 Agus 2019 & 0,6 & 2,7 & 0,8 & 7,2 & 24,19 \\
Rata-rata & & & & & 20,62 \\
\hline
\end{tabular}

Tabel 9. Nilai Beban Pencemaran Parameter TSS (mg/L)

\begin{tabular}{lccccc}
\hline \multicolumn{1}{c}{$\begin{array}{c}\text { Stasiun/ } \\
\text { Ulangan/Tg1 }\end{array}$} & $\begin{array}{c}\text { Kec arus } \\
(\mathbf{m} / \mathbf{d t})\end{array}$ & $\begin{array}{c}\text { Lebar } \\
(\mathbf{m})\end{array}$ & $\begin{array}{c}\text { Dalam } \\
(\mathbf{m})\end{array}$ & $\begin{array}{c}\text { Konsentsi } \\
(\mathbf{M g} / \mathbf{L})\end{array}$ & $\begin{array}{c}\text { BP } \\
\text { (Ton/bln) }\end{array}$ \\
\hline S2 & & & & & \\
1 / 6 Juli 2019 & 0,3 & 2,7 & 0,8 & 96 & 161,24 \\
2 / 13 Juli 2019 & 0,2 & 2,7 & 0,8 & 20 & 22,39 \\
3 / 20 Juli 2019 & 0,6 & 2,7 & 0,8 & 50 & 64,80 \\
4 / 28 Juli 2019 & 0,6 & 2,7 & 0,8 & 38 & 127,65 \\
5 / 3 Agus 2019 & 0,6 & 2,7 & 0,8 & 40 & 134,37 \\
Rata-rata & & & & & 102,09 \\
\hline
\end{tabular}

Nilai Beban Pencemaran TDS dan TSS pada stasiun S2 dipengaruhi oleh kecepatan arus, lebar, dalam aliran air dan konsentrasi masing-masing parameter, pada setiap tanggal pengukuran . Kondisi eksisting aliran air Stasiun S2 memiliki luas 2,16 $\mathrm{m}^{2}$ tergolong dangkal, mengakibatkan kondisi aliran air 
yang stabil dan tenang, sehingga konsentrasi TDS dan TSS berfluktuasi, bergantung pada aktivitas penambangan galian $C$ (sirtu) dan besarnya laju erosi rata-rata pada kemiringan $0-8 \%$ adalah 16,1 ton/ha/tahun dan $8-15 \% 72,7$ ton/ha/tahun (TBE berat sampai dengan sangat berat), akibat curah hujan yang cukup tinggi mendorong dan membawa tanah liat, lumpur, pasir dan bahan-bahan organik terlarut masuk ke aliran air Stasiun S2.

Menurut Effendi (2015), padatan terlarut total (TDS) dan padatan tersuspesi total (TSS) adalah bahan-bahan terlarut berupa senyawa-senyawa kimia anorganik yang biasa ditemukan di perairan, diantaranya Sodium (Na), Kalsium ( $\mathrm{Ca})$, Mangnesium $(\mathrm{Mg})$, bikarbonat $\left(\mathrm{HCO}_{3}\right)$, Besi $(\mathrm{Fe})$, Karbonat $\left(\mathrm{CO}_{3}\right)$, Silika $\left(\mathrm{SO}_{2}\right)$ dan lain-lain. Bahan-bahan tersuspensi dan terlarut pada perairan alami tidak bersifat toksik, akan tetapi jika berlebihan, terutama TSS dapat meningkatkan nilai kekeruhan, yang selanjutnya akan menghambat penetrasi cahaya matahari dan akhirnya berpengaruh terhadap proses fotosintesis di perairan.Kapasitas asimilasi beban pencemaran TDS dan TSS stasiun S3 disajikan pada Tabel 10.

Tabel 10. Kapasitas Asimilasi Beban Pencemaran TDS dan TSS pada Stasiun S3 Anak Sungai Kampar Sekitar Penambangan Galian C (sirtu)

\begin{tabular}{lccccc}
\hline $\begin{array}{l}\text { Para- } \\
\text { meter }\end{array}$ & Fungsi Y & $\mathrm{R}^{2}$ & $\begin{array}{c}\text { BM }^{*} \\
(\mathrm{Y})\end{array}$ & $\begin{array}{c}\text { Kapasitas Asimilasi } \\
\text { (ton/bln) }\end{array}$ & $\begin{array}{c}\text { Beban pencemar } \\
\text { (ton/bln) }\end{array}$ \\
\hline TDS & $0,106 \mathrm{X}+6,550$ & 0,947 & 1.000 & $9.372,17$ & 20,62 \\
TSS & $0,016 \mathrm{X}+36,95$ & 0,002 & 50 & 815,63 & 102,9 \\
\hline
\end{tabular}

Keterangan : * PP No. 82 Tahun 2001, BM TDS dan TSS

Nilai Kapasitas Asimilasi TDS dan TSS pada Stasiun S3 Tabel 10, analog dengan konsentrasi parameter TDS dan TSS yang berada di bawah baku mutu. Status mutu air tidak tercemar pada stasiun S3 didukung oleh parameter fisika, kimia dan biologi. DHL rata-rata stasiun S3 adalah 22,97 $\mu \mathrm{mhos} / \mathrm{cm}$ yang berada pada range nilai DHL 20-1500 $\mu$ mhos/cm (perairan alami). Parameter $\mathrm{pH}$ rata-rata stasiun S3 adalah 5,55 yang berada pada range nilai $\mathrm{pH}$ 5,5-6, menggambarkan penurunan keaneragaman, jenis dan kelimpahan plankton (Effedi, 2015), hal ini tergambar pada parameter biologi penelitian ini. Parameter DO rata-rata stasiun S3 adalah $4 \mathrm{mg} / \mathrm{L}$, merupakan batas minimum kebutuhan oksigen bagi biota air untuk dapat hidup mengacu ke pada baku mutu Peraturan Pemerintah Nomor 82 Tahun 2001, sesuai dengan hasil penelitian Baherem et al. (2014) yang menyatakan bahwa ikan dan biota air lainnya hanya dapat hidup pada kondisi oksigen terlarut dalam air diatas 3-4 mg/L.

\section{Pengaruh Penambangan Galian C (sirtu) terhadap Kondisi Sosial dan Ekonomi Masyarakat di Desa Palung Raya Kecamatan Tambang}

Sosial ekonomi masyarakat penduduk yang tinggal di sekitar Sungai Kampar yang merasakan dampak dari aktivitas penambangan galian C (sirtu) secara langsung adalah Desa Palung Raya. Metode random sampling digunakan untuk pemilihan sampel 94 orang responden.Sebagian besar berpendapat $(48,9 \%)$ kegiatan penambangan galian C (sirtu) kadang-kadang dikelola oleh masyarakat setempat, 48,95\% berpendapat keberadaan penambangan galian $C$ (sirtu) tidak menambah penghasilan, $55,3 \%$ belum menudukung sepenuhnya keberadaan penambangan galian C (sirtu), 53,2\% merasa keberadaan penambangan galian $C$ (sirtu) belum meningkatkan kepedulian sosialdan $55,3 \%$ belum menudukung sepenuhnya keberadaan penambangan galian $\mathrm{C}$ (sirtu). Hal ini menunjukan keberadaan penambangan galian C (sirtu) di Desa Palung Raya Kecamatan Tambang Kabupaten Kampar belum mempengaruhi kehidupan masyarakat sekitar lokasi tambang, karena pemilik dan pekerja penambangan berasal dari luar Desa Palung Raya.

\section{Pengelolaan Kualitas Air Anak Sungai Kampar Sekitar Pertambangan Galian C (sirtu) di Desa Palung Raya Kecamatan Tambang}

Penambangan galian C (sirtu) di Desa Palung Raya berada di DAS Kampar, dimana akan terjadi perubahan tutupan lahan menjadi lahan terbuka sehingga memberi peluang tingkat erosi tinggi pada musim hujan. Tingkat erosi berat dan sangat berat dari hasil penelitian lahan penambangan galian C (sirtu) yang berada pada anak Sungai Kampar belum mempengaruhi kualitas air Sungai Kampar. Kualitas air anak sungai Kampar di lokasi penelitian masih memenuhi baku mutu Peraturan Pemerintah Nomor 82 Tahun 2001 tentang Pengelolaan Kualitas Air dan Pengendalian Pencemaran air.

Meskipun demikian pengendalian dan pengelolan laju erosi tanah di sekitar lokasi penambangan galian C (sirtu) perlu dilakukan agar padatan seperti tanah liat, lumpur, pasir dan bahan-bahan organik terlarut dari aktivitas penambangan tidak menurunkan nilai kapasitas asimilasi di bawah nilai beban pencemaran. Hal ini akan berdampak kepada penurunan kualitas air Sungai Kampar. 


\section{ZONA}

Jurnal Lingkungan

ISSN : 2502-6496 (Print)

Volume 4, No 2, Oktober 2019, p. 71-82

http://zona.pelantarpress.co.id

Pengelolaan wilayah pertambangan galian C (sirtu) khususnya di Desa Palung Raya dan Kecamatan Tambang Umumnya, dirumuskan berdasarkan hasil analisis pengaruh penambangan galian $C$ (sirtu) terhadap kualitas air anak Sungai Kampar, laju erosi, Indeks Pencemaran, Beban Pencemaran dan Kapasitas Asimilasi anak Sungai Kampar dan sosial dan ekonomi masyarakat.

Yudhistiraet al., (2011) menyatakan bahwa Strategi pengaturan kebijakan pemerintah terhadap penambangan pasir yang utama adalah penerapan peraturan perundang-undangan yang berlaku secara konsekuen dan memberdayakan masyarakat. Tugas pokok dan fungsi lembaga teknis yang bertanggung jawab dalam hal pertambangan dilaksanakan secara profesional, transparan dan akuntabel. Pada prinsipnya pengaturan kebijakan pemerintah dalam penambangan pasir adalah mengupayakan suatu sistem pengelolaan penambangan yang berwawasan lingkungan.

Pengelolaan wilayah pertambangan galian C (sirtu) mengacu kepada pada Keputusan Menteri Negara Lingkungan Hidup nomor 43 Tahun 1996 tentang Kriteria Kerusakan Lingkungan Bagi Usaha Atau Kegiatan Penambangan Bahan Galian Golongan C Jenis Lepas Di Dataran, yang menyatakan setiap penanggung jawab usaha atau kegiatan penambangan bahan galian golongan $C$ jenis lepas di dataran wajib untuk melaksanakan persyaratan- persyaratan yang telah ditetapkan pada izin yang diberikan. Peraturan Menteri Energi dan Sumber Daya Mineral nomor 26 Tahun 2018 tentang Pelaksanaan Kaidah Pertambangan yang baik dan Pengawasan Pertambangan Mineral dan Batubara, menyatakan reklamasi adalah kegiatan yang dilakukan sepanjang tahapan usaha pertambangan untuk menata, memulihkan, dan memperbaiki kualitas lingkungan dan ekosistem agar dapat berfungsi kembali sesuai peruntukkannya. Upaya pengelolaan lingkung dan upaya pemantauan lingkungan atau surat pernyataan pengelolaan lingkungan yang tertuang dalam dokumen lingkungan hidup dan kegiatan pasca tambang adalah kegiatan terencana dan sistimatis, dan berlanjut setelah akhir sebagaian atau seluruh kegiatan usaha pertambangan untuk memulihkan fungsi lingkungan alam dan fungsi sosial menurut kondisi lokal diseluruh wilayah pertambangan. Pengengelolaan kualitas air anak Sungai Kampar sekitar penambangan galian C (sirtu) disajikan pada Tabel 11.

Tabel 11. Analisis Pengelolaan Kualitas Air anak Sungai Kampar sekitar penambangan galian C (sirtu) di Desa Palung Raya Kecamatan Tambang Kabupaten Kampar

\begin{tabular}{|c|c|c|}
\hline No & Uraian & Pengelolaan \\
\hline 1 & $\begin{array}{l}\text { Kualitas air anak } \\
\text { Sungai Kampar }\end{array}$ & $\begin{array}{l}\text { - Penyusunan zonasi pertambangan yang memuat lokasi- } \\
\text { lokasi yang dicadangkan untuk penambangan galian C } \\
\text { (sirtu) berdasarkan keberadaan deposit bahan tambang } \\
\text { dan pertimbangan ekologi (sedang dilakukan oleh Dinas } \\
\text { ESDM Provinsi Riau). } \\
\text { - Menyusun peraturan daerah terkait kewenangan Provinsi } \\
\text { Riau dibidang pertambangan sebagai tindak lanjut dari } \\
\text { amanah peraturan perundang-undangan sebagai dasar } \\
\text { pencegahan lebih lanjut terhadap penurunan kualitas air } \\
\text { permukaan sekitar lokasi tambang dan kerusakan } \\
\text { lingkungan (sedang disusun oleh Dinas ESDM Provinsi } \\
\text { Riau). } \\
\text { - Meningkatkan koordinasi antar instasi teknis sehingga } \\
\text { pelaksanaan pengawasan lebih efektif } \\
\text { Kewenangan Pemerintah Provinsi Riau }\end{array}$ \\
\hline 2 & Laju erosi & $\begin{array}{l}\text { Reklamasi atau penanaman kembali area yang telah } \\
\text { ditambang (Pasca Tambang) akan menurunkan laju erosi di } \\
\text { lokasi penambangan galian C (sirtu) yang telah disusun pada } \\
\text { perencanaan pengelolaan lingkungan di lokasi penambangan } \\
\text { galian C (sirtu), sebagai syarat izin IUP yang diberikan } \\
\text { kepada pelaku usaha. } \\
\quad \text { Dilaksankan oleh Pemilik Izin dan diawasi oleh } \\
\text { instansi teknik pemerintah Kabupaten Kampar dan Provinsi } \\
\text { Riau. }\end{array}$ \\
\hline
\end{tabular}

$3 \quad$ Indeks

Pencemaran,

Beban

Pencemaran dan

Kapasitas

Asimilasi anak

Sungai Kampar
- Melakukan pemantauan kualitas air pada sumbersumber pencemar yang dapat menurunkan kualiatas air Sungai Kampar oleh instansi teknis terkait dengan lingkungan.

- Membuat Peraturan Gubernur tentang Baku Mutu Air Sungai Kampar, sehingga penentuan IP, perhitungan BP dan Nilai KA beban pencemar tidak lagi berpedoman 


\section{ZONA}

Jurnal Lingkungan

ISSN : 2502-6496 (Print)
Volume 4, No 2, Oktober 2019, p. 71-82

http://zona.pelantarpress.co.id
$4 \quad$ Sosial

ekonomi masyarakat kepada PP No. 82 Tahun 2001.

dan - Pemberdayaan ekonomi masyarakat berdasarkan potensi lokal, seperti pembibitan tanaman keras, kebun dan pertanian, harus dipertahankan.

- Pemerintah melalui dana desa memprioritaskan bantuan dana kepada masyarakat yang mengembangkan potensi lokal, karena dapat digunakan untuk tanaman tutupan lahan yang terbuka di lokasi penambangan

Pemilik Izin, Pemerintah Kabupaten Kampar dan Provinsi Riau.

\section{KESIMPULAN}

Penambangan galian C (sirtu) belum berpengaruh terhadap kualitas air anak Sungai Kampar di Desa Palung Raya Kecamatan Tambang Kabupaten Kampar, meskipun di stasiun pengamatan S1 (sebelum penambangan), S2 (sumber pencemar), S3 dan S4 (pemukiman penduduk) parameter fisika dan kimia mengalami fluktuasi dan rata-rata hasil pengukuran belum melampaui baku mutu PP Nomor 82 Tahun 2001, analog dengan parameter biologi plankton dimana keaneragaman sedang, tidak ada jenis yang dominan dan keseragaman seimbang.

Laju erosi rata-rata sekitar penambangan galian C (sirtu) di Desa Palung Raya pada kemiringan 0 $8 \%$ adalah 16,1 ton/ha/tahun dengan TBE sedang, dan pada kemiringan $8-15 \%$ adalah 72,7 ton/ha/tahun dengan TBE sangat berat, belum menurunkan kualitas air anak Sungai Kampar, dimana konsentrasi TDS dan TSS rata-rata pada setiap stasiun pengamatan masih di bawah baku mutu.Penambangan galian C (sirtu) di sekitar anak Sungai Kampar di Desa Palung Raya belum mempengaruhi nilai Indeks Pencemar dengan status mutu pada stasiun S1, S2, S3 (sekitar lokasi penambangan) memenuhi baku mutu dan S4, S5 (pemukiman penduduk) setelah penambangan cemar ringan, analog dengan hasil pemantauan Sungai Kampar lokasi pasar Danau tahun 2017 dan 2018 status mutu air cemar ringan. Beban pencemar pada sumber pencemar stasiun S2 parameter TDS 26,62 ton/bulan dan TSS 102,09 ton/bln. Nilai kapasitas asimilasi beban pencemar pada stasiun S3 yang berjarak lebih kurang 50 meter setelah stasiun S2 parameter TDS 9.372, 17 ton/bln dan TSS 815,63 ton/bln diatas nilai beban pencemar stasiun S2 yang masuk ke stasiun S3. Keberadaan penambangan galian C (sirtu) di Desa Palung Raya Kecamatan Tambang Kabupaten Kampar belum mempengaruhi kehidupan masyarakat sekitar lokasi tambang, dimana aktivitas bertani dan nelayan masih bisa dilakukan.Pengelolaan wilayah pertambangan galian C (sirtu) khususnya di Desa Palung Raya dan Kecamatan Tambang Umumnya dirumuskan berdasarkan hasil analisis pengaruh penambangan galian $\mathrm{C}$ (sirtu) terhadap kualitas air anak Sungai Kampar, laju erosi, Indeks Pencemaran, Beban Pencemaran, dan Kapasitas Asimilasi anak Sungai Kampar dan sosial dan ekonomi masyarakat sekitar lokasi penambangan.

\section{DAFTAR PUSTAKA}

Asdak, C. 2007. Hidrologi dan Pengelolaan DAS. Gadjah Mada University Press. Yogyakarta. Hal 338 391.

Baherem, Suprihatin dan S.I. Nastiti. 2014. Strategi Pengelolaan Sungai Cibanten Provinsi Banten Berdasarkan Analisis Daya Tampung BebanPencemaran Air dan Kapasitas Asimilasi. Jurnal Sumber Daya Alam dan Lingkungan IPB, 4 (1) : 60-69.

Dinas Lingkungan Hidup dan Kehutanan Provinsi Riau. 2017. Laporan Pemantauan Kualitas Air Sungai Kampar Tahun 2017. Dinas Lingkungan Hidup dan Kehutan Provinsi Riau, Pekanbaru.

Effendi, H. 2015. Telaah Kualitas air. Kanisius. Yogyakarta. hal $63-82$.

Hamid, D. 2017. Prospek Pengembangan Bahan Galian Golongan C (Pasir dan Batu Kerikil) di Kabupaten Kampar (Studi Kasus Desa Pulau Permai Kecamatan Tambang).JOM Fekon Unri, 4(1):66-77.

Kementerian Energi dan Sumber Daya Mineral. 2018. Keputusan Menteri Energi dan Sumber Daya Mineral RI Nomor 26 Tahun 2018 tentang Pelaksanaan Kaidah Pertambangan yang baik dan Pengawasan Pertambangan Mineral dan Batubara. 


\section{ZONA}

Jurnal Lingkungan

ISSN : 2502-6496 (Print)

Volume 4, No 2, Oktober 2019, p. 71-82 http://zona.pelantarpress.co.id

Odum, E. P. 1996. Dasar-Dasar Ekologi, Terjemahan Cjahjono Samingan. Edisi ketiga. Gajah Mada University Press, Jogyakarta. Hal. 178 - 179.

Pemerintah Provinsi Riau. 2013. Laporan Akhir Penyusunan Daya Dukung dan Daya Tampung Lingkungan Hidup Provinsi Riau. Bappeda Provinsi Riau, Pekanbaru.

Presiden RI. 2001. Peraturan Pemerintah Nomor 82 Tahun 2001 tentang Pengelolaan Kualitas Air dan Pengendalian Pencemaran Air. Sekretaris Negara. Jakarta.

Rizqan A., I. Mahyudin I, M. Rahman dan J. Hadie. 2016. Status Kualitas Air Sungai Sekitar Kawasan Penambangan Pasir Di Sungai Batang Alai Desa Wawai Kalimantan Selatan.Enviro Scienteae, 12(1):1-6.

Sembel L. 2012. Analisis Beban Pencemar dan Kapasitas Asimilasi di Estuari Sungai Belau Teluk lampung. Maspari Journal, 4(2): 178-183.

Situmorang, M. 2017. Kimia Lingkungan. Rajagrafindo Persada. Jakarta. Hal 45 - 54.

Sofarini, D. 2011. Karakteristik Fisik-Kimia Kualitas Air pada Lahan Bekas Tambang Bahan Galian Golongan C di Kecamatan Landasan Ulin Kota Banjarbaru.Jurnal Enviro Scientea,7(1) : 6-11.

Sudinno D. 2012. Kapasitas Asimilasi Perairan Pesisir Kabupaten Sidoarjo terhadap Produktivitas Budidaya Udang dampak pembuangan lumpur Lapindo. Jurnal JPPIK, 6(1) : 12-19.

Suherman D.W., D.T. Suryaningtyas, dan S. Mulatsih . 2015.Dampak Penambangan Pasir terhadap Kondisi Lahan dan Air di Kecamatan Sukaratu Kabupaten Tasikmalaya.Jurnal Pengelolaan Sumber Daya Alam dan Lingkungan, 5 (2): 99-105.

Yanti, H., Y.I. Siregar dan S. Anita. 2014. Analisis Beban Pencemar dan Kapasitas Asimilasi Logam Berat di Perairan Sungai Setingkai Kecamatan Kampar Kiri Kabupaten Kampar. Jurnal Ilmu Lingkungan Unri, 8(1) : 27-37.

Yudhistira, W. K. Hidayat dan A. Hadiyarto. 2011. Kajian Dampak Kerusakan Lingkungan Akibat Kegiatan Penambangan Pasir di Desa Keningar Daerah Kawasan Gunung Merapi. Jurnal Ilmu Lingkungan Undip, 9(2) : 76-84. 